\title{
Extending the use of an underutilised tuber I: Physicochemical and pasting properties of cocoyam (Xanthosoma sagittifolium) flour and its suitability for making biscuits
}

\author{
Shirley Isibhakhomen EJOH $^{1 *}$, Veronica Adeoti OBATOLU ${ }^{2}$, Oyeyoyin Taiwo OLANIPEKUN ${ }^{2}$ \\ and Elizabeth Oluremi FARINDE ${ }^{2}$ \\ ${ }^{1}$ Department of Human Nutrition, University of Ibadan, Ibadan, Oyo State, Nigeria. \\ ${ }^{2}$ Institute of Agricultural Research and Training (IAR\&T), Obafemi Awolowo University. P.M.B. 5029, Moor Plantation, \\ Ibadan, Oyo State. Nigeria.
}

Accepted 7 August, 2013

\begin{abstract}
Cocoyam is one of the important root food crops especially among the low income earners in Nigeria. However, the utilisation options of cocoyam are mainly limited to direct consumption as whole boiled or pounded tuber only, thus making it an underutilised crop. Physicochemical and pasting properties of cocoyam flour, its suitability and acceptability in biscuit making were determined. Red and white cocoyam varieties were processed into flour by sun-drying method. The physicochemical and pasting properties were compared with that of commercial wheat flour (CWF). Cocoyam flour and wheat flour blend in the ratio 10:90, 20:80, 50:50 and 100\% were used to prepare biscuits and sensory evaluation was conducted. Blanched cocoyam flours had significantly higher $(p<0.05)$ starch and amylose content than the unblanched flours: 21.36 and $21.87 \%$ starch; 44.35 and $44.20 \%$ amylose, blanched white cocoyam flour (BI-WCF) and blanched red cocoyam flour (BI-RCF), respectively; 21.12 and $15.56 \%$ starch and 39.36 and $\mathbf{4 3 . 3 9 \%}$ amylose, unblanched white cocoyam flour (U-WCF) and unblanched red cocoyam flour (U-RCF), respectively. Peak viscosity was significantly higher $(p<0.05)$ in blanched flours (262.79RVU and 267.58RVU, BI-WCF and BI-RCF, respectively) than in unblanched flours and CWF (161.79RVU, 200.58RVU and 145.54RVU, U-WCF, U-RCF and CWF, respectively). Sensory evaluation showed that biscuits made from two flour blends had high acceptability especially at $10 \%$ substitution level.
\end{abstract}

Key words: Cocoyam flour, physicochemical properties, pasting properties, biscuits, sensory evaluation

\section{INTRODUCTION}

Cocoyam (Xanthosoma sagittifolium) belongs to the family Araceae. It is one of the six most important root and tuber crops world-wide (Jennings, 1987; Onwueme and Charles, 1994). The corm, cormel and leaves are important source of carbohydrates for human nutrition, animal feed (Ndoumou et al., 1995; Nyochembeng and
Garton, 1998) and of cash income for farmers in Asia, Africa, and Latin America (Onwueme and Charles, 1994). It is grown by farmers with small holdings mainly for its edible tubers and is used as subsistence staple in many parts of Nigeria in particular and generally in the arid subtropics in Africa. The average production figure for 


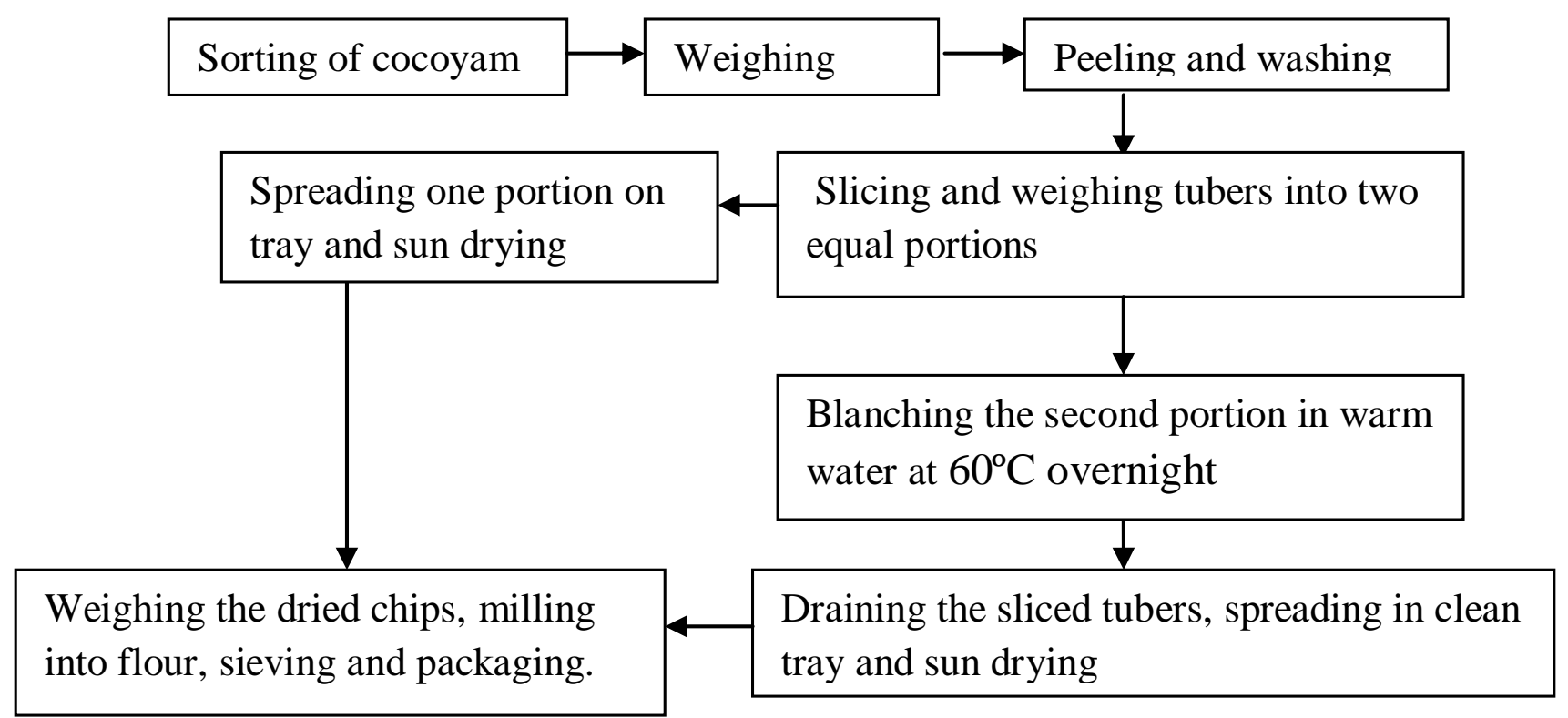

Figure 1. Flow chart for the processing of cocoyam tuber into flour.

Nigeria is 5,068,000 metric tonnes which accounts for about $37 \%$ of total world output of cocoyam (FAO, 2007).

In Nigeria, cocoyam is one of the important root food crops especially among the low income earners. However, the use of cocoyam is limited to direct consumption through boiling of the tuber, frying in oil or pounding into fufu (a dumpling similar to pounded yam) and eaten with soup and it is also used in thickening soups especially in eastern Nigeria. Cocoyam, despite its uses, is regarded as an underutilized tuber, and an insufficiently studied crop (Watanabe, 2002). This is partly because it suffers very stiff competition from yam and cassava, which is preferred for consumption. The palatability problems of cocoyam: bitter and astringent taste and scratchiness in the mouth and throat, as reported by Sefa-Dedeh and Agyir-Sackey (2004) and Iwuoha and Kalu (1995), has also contributed to its being less accepted and thus categorized as an underutilized tuber crop.

Unlike cocoyam, the extended uses of other tuber crops such as cassava and sweet potato have been extensively investigated especially in flour production. These have been used to make composite flour with wheat flour for a variety of pastry products, which have market value and have contributed to reduced importation of wheat flour (Sanful and Darko, 2010). However cocoyam remains an underexploited tuber crop in this regard. The utilization and market options of cocoyam are very limited due to limited processing and utilisation options. Low quality cocoyam flour and dried chips are the cocoyam products which are traditionally processed for small scale and household use. Hence, cocoyam flour is not yet a commercially traded product in Nigeria. Little adaptive research to substitute wheat flour with cocoyam flour in pastry making has been done. It could be assumed that a partial wheat flour substitution with cocoyam flour like other root tubers and grain flour in snack processing will extend the uses of cocoyam tuber. If adopted, it will generate income for cocoyam farmers and processors, as well as provide varieties of nutritious snack items that will be available and acceptable to consumers.

The aim of the study was to determine the physicochemical and pasting properties of cocoyam flour from two processing techniques, and assess the suitability of cocoyam and wheat flour blend quality for preparing biscuits.

\section{MATERIALS AND METHODS}

\section{Collection and preparation of test samples}

White and red varieties of cocoyam tubers used in this study were purchased from Omi market in Oyo State, Nigeria.

\section{Flour Production}

Two types of cocoyam flour were prepared from peeled red and white cocoyam tubers. Each of the varieties were cut into chips, and divided into two equal halves. They were given two treatments: one half was sundried directly before dry milling, while the other half was blanched before sun drying and milling into flour, for white and red cocoyam tubers respectively (Figure 1). The two treatments yielded four different flours: 1) Red cocoyam flour (sundried only); 2) White cocoyam flour (sundried only); 3) Red cocoyam flour (soaked in warm water and sundried) and 4) White cocoyam flour (soaked in warm water and sundried). 
Table 1. Flour cocoyam flour/ wheat flour substitution levels (10, $30,50,100 \%)$.

\begin{tabular}{lccc}
\hline Sample code & $\begin{array}{c}\text { White cocoyam } \\
\text { flour (\%) }\end{array}$ & $\begin{array}{c}\text { Red cocoyam } \\
\text { flour (\%) }\end{array}$ & $\begin{array}{c}\text { Wheat } \\
\text { flour (\%) }\end{array}$ \\
\hline A & - & - & 100 \\
B & 10 & - & 90 \\
C & 20 & - & 80 \\
D & 50 & - & 50 \\
E & 100 & - & \\
F & - & 10 & 90 \\
G & - & 20 & 80 \\
H & - & 50 & 50 \\
I & - & 100 & - \\
\hline
\end{tabular}

\section{Laboratory analysis}

The cocoyam flour were assessed for their total starch content, amylose and amylopectin content as well as their pasting properties using Rapid visco analyser model RVA Newport Scientific Super Model 3 with a Computer IBM compatible, capable of running RVA control software. The following were recorded: peak viscosity, trough, breakdown, final viscosity, setback from trough, peak time and pasting temperature. Commercial wheat flour was also analysed for the same parameters as control. The physicochemical and pasting properties of the samples were carried out in duplicates.

\section{Experimental design and product development (using the unblanched red and white cocoyam flour)}

Ten (10) biscuits constituted the experimental conditions (manipulations). The manipulations (that is substitution levels with wheat flour) were: sample A was produced with $100 \%$ all purpose wheat flour (Dangote brand) $(250 \mathrm{~g})$; B produced with $90 \%$ wheat flour and 10\% white cocoyam flour $(175 \mathrm{~g} / 25 \mathrm{~g})$; C produced with $70 \%$ wheat flour and $30 \%$ white cocoyam flour (125 g/7g); D produced with $50 \%$ wheat flour and $50 \%$ white cocoyam flour (125 $\mathrm{g} / 125 \mathrm{~g}) ; 100 \%$ white cocoyam flour $(250 \mathrm{~g})$; E produced with $90 \%$ wheat flour and $10 \%$ red cocoyam flour $(175 \mathrm{~g} / 25 \mathrm{~g}) ; \mathrm{F}$ produced with $70 \%$ wheat flour and $30 \%$ red cocoyam flour $(125 \mathrm{~g} / 75 \mathrm{~g})$; G produced with $50 \%$ wheat flour and $50 \%$ red cocoyam flour (125 $\mathrm{g} / 125 \mathrm{~g}$ ); I produced with $100 \%$ red cocoyam flour $(250 \mathrm{~g})$; J produced with commercially sold biscuit (coastal biscuit). The quantities of all other ingredients namely: margarine $(125 \mathrm{~g})$, sugar $(55 \mathrm{~g})$, salt $(2.5 \mathrm{~g})$, baking powder $(5 \mathrm{~g})$, grated nutmeg $(1.5 \mathrm{~g})$, vanilla essence $(5 \mathrm{ml})$ and water $(60-65 \mathrm{ml})$, remained constant.

The biscuits were produced according to the recipe described by Sanni et al. (2006) for cassava cookies with slight modifications. All dry ingredients were first weighed into a clean dry plastic bowl and thoroughly mixed. Margarine was added to the content of the bowl and mixed; finally water was added to achieve non sticky soft dough. The dough was placed on a floured wooden work table, rolled out and cut into round shapes with a biscuit cutter. The surface was pricked with a fork to prevent the dough from rising. The biscuits were baked in a hot oven set at $175^{\circ} \mathrm{C}\left(350^{\circ} \mathrm{F}\right)$ for 30 35 minutes.

\section{Sensory evaluation: participants}

Eighty five (85) undergraduate students of the University of Ibadan participated as panelist (untrained). Each participant evaluated all 10 biscuit samples (A to $\mathrm{J}$ ) to rate the sensory attributes of colour, appearance, taste, flavor, texture, and overall acceptability using a 5 - point hedonic scale: 5 , like extremely; 4, like slightly; 3 , neither like nor dislike; 2, dislike slightly; 1 , dislike extremely. Groups of 10 student panelist were used in every instant for the sensory evaluation exercise. Necessary precautions were taken to prevent carryover of flavor during the test by ensuring that panelists rinsed their mouth properly with clean drinking water after evaluating each biscuit.

\section{Statistical analysis}

Statistical Package for the Social Sciences (SPSS version 17.0) was used for analysis. One way ANOVA was used to compare the means of the physicochemical and pasting properties of the wheat flour and cocoyam flours. Duncan multiple range test was used for mean separation. Repeated measures one-way ANOVA design (that is within subjects design, whereby each participant evaluated all ten biscuit samples) was used to compare the means for each sensory attribute of the biscuits. The biscuits were the independent variables (IV), while the ratings based on the 5 - point hedonic scale was the dependent variable (DV).

\section{RESULTS}

The results of the physicochemical characteristics (sugar, starch, amylose and amylopectin content, swelling capacity and solubility) of cocoyam flours and commercial wheat flour are presented in Table 2. The sugar content of all the samples analysed ranged from 0.205 to $0.852 \%$, unblanched white cocoyam flour (U-WCF) and unblanched red cocoyam flour (U-RCF), respectively. The values obtained for commercial wheat flour (CWF) and U-RCF were not significantly different $(p<0.05)$. The starch content of the cocoyam flour samples ranged from $15.563 \%$ (U-RCF), to $21.874 \%$ blanched red cocoyam flour (BI-RCF). The starch content of the blanched flours were significantly different $(p<0.05)$ from starch content of the unblanched flours. The percentage amylose content of the flour samples showed that CWF, had the least 
Table 2. Physicochemical characteristics of cocoyam flour and commercial wheat flour.

\begin{tabular}{lcccccc}
\hline Treatment & \%Sugar & \%Starch & \%Amylose & \%Amylopectin & Swelling power & \%Solubility \\
\hline CWF & $0.79 \pm 0.05^{\mathrm{a}}$ & $21.28 \pm 0.15^{\mathrm{b}}$ & $31.23 \pm 0.07$ & $68.77 \pm 0.07^{\mathrm{d}}$ & $9.19 \pm 0.74^{\mathrm{a}}$ & $10.11 \pm 1.21^{\mathrm{c}}$ \\
U-WCF & $0.21 \pm 0.04^{\mathrm{d}}$ & $21.12 \pm 0.08^{\mathrm{b}}$ & $39.36 \pm 0.14$ & $60.64 \pm 0.14^{\mathrm{c}}$ & $10.97 \pm 0.28^{\mathrm{a}}$ & $14.44 \pm 0.01^{\mathrm{ab}}$ \\
U-RCF & $0.85 \pm 0.01^{\mathrm{a}}$ & $15.57 \pm 0.35$ & $43.39 \pm 0.14$ & $56.61 \pm 0.14^{\mathrm{b}}$ & $11.36 \pm 0.18^{\mathrm{a}}$ & $16.14 \pm 1.08^{\mathrm{ab}}$ \\
BI-WCF & $0.33 \pm 0.04^{\mathrm{c}}$ & $21.37 \pm 0.32^{\mathrm{ab}}$ & $44.35 \pm 0.07$ & $55.65 \pm 0.07^{\mathrm{a}}$ & $10.63 \pm 2.21^{\mathrm{a}}$ & $14.01 \pm 0.29^{\mathrm{b}}$ \\
BI-RCF & $0.58 \pm 0.01^{\mathrm{b}}$ & $21.88 \pm 0.04^{\mathrm{a}}$ & $44.20 \pm 0.14$ & $55.80 \pm 0.14^{\mathrm{a}}$ & $11.74 \pm 0.03^{\mathrm{a}}$ & $14.45 \pm 0.13^{\mathrm{a}}$ \\
\hline
\end{tabular}

CWF, Commercial wheat flour; U-WCF, unblanched white cocoyam flour ; U-RCF, unblanched red cocoyam flour; BIWCF, blanched white cocoyam flour; BI-RCF, blanched red cocoyam flour. Means with the same letter in the same column are not significantly different $p<0.05$.

Table 3. Pasting Properties of cocoyam flour.

\begin{tabular}{lccccccc}
\hline Treatment & Peak Viscosity & Trough & Breakdown & Final viscosity & Set back & Peak time & Pasting temp $\left({ }^{\circ} \mathrm{C}\right)$ \\
\hline CWF & $145.54 \pm 5.60^{\mathrm{d}}$ & $84.54 \pm 8.78^{\mathrm{c}}$ & $61.00 \pm 3.18^{\mathrm{ab}}$ & $170.13 \pm 7.49^{\mathrm{d}}$ & $85.59 \pm 1.29^{\mathrm{c}}$ & $5.93 \pm 0.18^{\mathrm{a}}$ & $61.95 \pm 0.42^{\mathrm{a}}$ \\
U-WCF & $161.80 \pm 4.77^{\mathrm{c}}$ & $155.88 \pm 3.71^{\mathrm{b}}$ & $5.92 \pm 1.06^{\mathrm{d}}$ & $243.88 \pm 4.42^{\mathrm{c}}$ & $88.00 \pm 0.71^{\mathrm{c}}$ & $5.77 \pm 0.04^{\mathrm{a}}$ & $61.73 \pm 0.04^{\mathrm{a}}$ \\
U-RCF & $200.59 \pm 5.54^{\mathrm{b}}$ & $165.38 \pm 5.83^{\mathrm{b}}$ & $35.21 \pm 0.30^{\mathrm{c}}$ & $270.38 \pm 1.70^{\mathrm{b}}$ & $105.00 \pm 4.13^{\mathrm{b}}$ & $5.04 \pm 0.12^{\mathrm{b}}$ & $61.93 \pm 0.39^{\mathrm{a}}$ \\
BI-WCF & $262.79 \pm 2.42^{\mathrm{a}}$ & $197.34 \pm 0.64^{\mathrm{a}}$ & $58.92 \pm 3.06^{\mathrm{b}}$ & $312.75 \pm 4.48^{\mathrm{a}}$ & $108.88 \pm 5.13^{\mathrm{b}}$ & $4.97 \pm 0.07^{\mathrm{b}}$ & $61.78 \pm 0.04^{\mathrm{a}}$ \\
BI-RCF & $267.58 \pm 5.30^{\mathrm{a}}$ & $203.88 \pm 2.24^{\mathrm{a}}$ & $70.25 \pm 7.54^{\mathrm{a}}$ & $316.17 \pm 2.83^{\mathrm{a}}$ & $118.84 \pm 0.59^{\mathrm{a}}$ & $4.78 \pm 0.12^{\mathrm{b}}$ & $61.80 \pm 0.00^{\mathrm{a}}$ \\
\hline
\end{tabular}

Means with the same letter in the same column are not significantly different $p<0.05$.

Table 4. Gender and age of participants.

\begin{tabular}{lcc}
\hline Parameter & Frequency & Percent (\%) \\
\hline Gender & & \\
Male & 22 & 29.3 \\
Female & 53 & 70.7 \\
& & \\
Age & & \\
$<20 y r s$ & 41 & 54.7 \\
20-25yrs & 27 & 36.0 \\
26-30yrs & 4 & 5.3 \\
$>30 y r s$ & 2 & 2.7 \\
\hline
\end{tabular}

amylose content (31.23\%), followed by U-WCF, which contained $39.36 \%$. Amylose content of BI-WCF and BI$\mathrm{RCF}$, were not significantly different at $(p<0.05)$, but the amylose content of CWF, U-WCF and U-RCF were significantly different at $(p<0.05)$. The swelling power of all the samples were not significantly different $(p<0.05)$.

Table 3 shows the pasting properties of cocoyam flours and commercial wheat flour. The peak viscosity (PV) and final viscosity $(F V)$ of all the samples were significantly different $(p<0.05)$ except for BI-WCF and BI-RCF which were not significantly different $(p>0.05)$. Set back between CWF and U-WCF were not significantly different; U-RCF and BI-WCF, were not significantly different $(p>0.05)$. Peak time for CWF and U-WCF were not significantly different; U-RCF, BI-WCF and BI-RCF, were not significantly different ( $p>0.05)$.

There were significant differences in breakdown viscosities of blanched and unblanched cocoyam flours $(p<0.05)$. The peak time which is a measure of the cooking time was not significantly different between CWF and U-WCF ( $p>0.05$ ); U-RCF, BI-WCF and BI-RCF, were also not significantly different $(p>0.05)$.

CWF had the highest value $(5.93 \pm 0.18)$ for peak time while $\mathrm{BI}-\mathrm{RCF}$ had the least value $(4.78 \pm 0.12)$. Pasting temperature for all flour samples analysed, were not significantly different from each other $(p>0.05)$; the values ranged from $61.73 \pm 0.04^{\circ} \mathrm{C}(\mathrm{BI}-\mathrm{WCF})$ to $62.95 \pm 0.42^{\circ} \mathrm{C}$ (CWF).

Table 4 shows the gender and age distribution of the participants (untrained panelists): $29.3 \%$ were male, and $70.7 \%$ were female. About $54.7 \%$ of the participants were less than 20 years of age; $36 \%$ were between $20-25$ years; $5.3 \%$ were 26 - 30 year and $2.7 \%$ were above 30 years.

Table 5 shows the mean ratings of the sensory attributes of the biscuit products by 85 untrained panelists. Repeated measures ANOVA was conducted to assess whether there were differences between the average ratings of the sensory attributes of the 10 biscuit products: colour, appearance, flavor, taste, texture and overall acceptability.

The results in Table 5 show that there was significant difference in the ratings of the sensory attributes of the 10 biscuits by the participants: biscuit crust colour; $F(7.37$, 
Table 5. Sensory evaluation of biscuits products from wheat/cocoyam flour blend.

\begin{tabular}{llllllc}
\hline Sample code & Colour & Appearance & Flavor & Taste & Texture & Overall acceptability \\
\hline A & $4.36 \pm 0.80$ & $4.08 \pm 1.09$ & $4.39 \pm 0.85$ & $4.44 \pm 0.76$ & $4.36 \pm 0.86$ & $4.58 \pm 0.61$ \\
B & $3.75 \pm 1.06$ & $3.42 \pm 1.16$ & $3.81 \pm 0.97$ & $3.86 \pm 1.07$ & $4.02 \pm 1.06$ & $3.85 \pm 0.94$ \\
C & $3.66 \pm 1.04$ & $3.51 \pm 1.12$ & $3.56 \pm 1.05$ & $3.78 \pm 1.08$ & $3.96 \pm 0.95$ & $3.73 \pm 1.05$ \\
D & $3.19 \pm 1.29$ & $3.16 \pm 1.23$ & $3.39 \pm 1.17$ & $3.08 \pm 1.26$ & $3.26 \pm 1.10$ & $3.14 \pm 1.05$ \\
E & $2.68 \pm 1.42$ & $2.71 \pm 1.33$ & $2.68 \pm 1.05$ & $2.01 \pm 1.06$ & $3.25 \pm 1.14$ & $2.42 \pm 1.07$ \\
F & $3.98 \pm 1.02$ & $3.64 \pm 1.11$ & $3.85 \pm 0.93$ & $3.91 \pm 1.01$ & $4.20 \pm 0.90$ & $4.00 \pm 0.82$ \\
G & $3.54 \pm 1.14$ & $3.34 \pm 1.18$ & $3.58 \pm 1.10$ & $3.40 \pm 1.24$ & $3.72 \pm 1.03$ & $3.56 \pm 0.97$ \\
H & $3.59 \pm 1.26$ & $3.56 \pm 1.28$ & $3.35 \pm 1.21$ & $3.13 \pm 1.18$ & $3.31 \pm 1.25$ & $3.20 \pm 1.12$ \\
I & $3.49 \pm 1.49$ & $3.65 \pm 1.47$ & $3.26 \pm 1.26$ & $2.67 \pm 1.37$ & $3.46 \pm 1.27$ & $3.07 \pm 1.40$ \\
J & $4.39 \pm 0.96$ & $4.35 \pm 1.05$ & $3.80 \pm 1.14$ & $4.09 \pm 1.05$ & $4.65 \pm 0.63$ & $4.29 \pm 0.84$ \\
\hline
\end{tabular}

A, $100 \%$ wheat flour biscuit; B, $90 \%$ wheat flour/10\%white cocoyam flour biscuit; C, $70 \%$ wheat flour/30\%white cocoyam flour biscuit; D, $50 \%$ wheat flour/ $50 \%$ white cocoyam flour biscuit; E, $100 \%$ white cocoyam flour biscuit; F, $90 \%$ wheat flour/ $10 \%$ red cocoyam flour biscuit; G, $70 \%$ wheat flour/ $30 \%$ red cocoyam flour biscuit; $\mathrm{H}, 50 \%$ wheat flour $/ 50 \%$ red cocoyam flour biscuit; I, 100\% red cocoyam flour biscuit; J, commercially sold biscuit (coastal biscuit).

$618.86)=19.84, \mathrm{p}<0.001$, eta $^{2}=.19 ;$ appearance; $\mathrm{F}$ $(7.35,617.14)=14.73, p<.001$, eta $^{2}=.15 ;$ flavor $($ aroma $)$; $\mathrm{F}(8.47,711.44)=19.37, \mathrm{p}<0.001$ eta $^{2}=.19 ;$ taste; $\mathrm{F}(9$, $756)=41.71, \mathrm{p}<0.001$, eta $^{2}=.33$; texture; F $(8.29$, $687.68)=24.46, p<0.001$, eta ${ }^{2}=.23$; overall acceptability; $F(8.15,676.33)=40.29, p<0.001$, eta $^{2}=.33$. Apart from biscuit taste (because Mauchly's test of sphericity was not significant, hence sphericity was assumed), all the other sensory attributes were done with Huynh-Feldt correction (because Mauchly's test of sphericity was significant and epilsons was $>.75$ ).

The means and standard deviations for the 10 biscuit products were listed in order of highest to least percentage wheat flour content and white cocoyam flour content (Table 1) and highest percentage wheat flour content and red cocoyam flour content (Table 1). Product $\mathrm{J}$ is a commercially sold biscuit (coastal biscuit) which served as control.

An examination of these means suggests that participants rated the biscuit products having more wheat flour content better than the biscuit products with higher cocoyam flour content. The polynomial contrasts are indicated in support of this: there was significant quadratic trend for biscuit crust colour and biscuit texture $(p<0.001)$, and there was significant linear and quadratic trend for biscuit appearance, taste, and overall acceptance $(p<0.05, p<0.001$, respectively). For biscuit flavor, the linear, quadratic and cubic trends were significant $(p<0.001, p<0.001, p<0.05$, respectively).

\section{Non parametric test}

A Friedman test was conducted to assess if there were differences among the mean ranks of the biscuit sensory attribute ratings; biscuit crust colour: $\mathrm{x}_{2}^{2}(9, \mathrm{~N}=85)=$ 127.59, $p<0.001$; biscuit appearance: $X^{2}(9, N=85)=$
115.52, $\mathrm{p}<0.001$; biscuit flavor (aroma): $\mathrm{x}^{2}(9, \mathrm{~N}=85)=$ 146.37, $p<0.001$; biscuit taste: $X^{2}(9, N=85)=247.65$, $p<0.001$; biscuit texture: $x^{2}(9, N=84)=193.57, p<0.001$; biscuit overall acceptance: $X^{2}(9, N=84)=258.13$, $\mathrm{p}<0.001$.

The results indicate that there were differences among the 10 mean ranks of the sensory attributes and orthogonal contrasts were performed using Wilcoxon tests with Bonferroni correction to ascertain the pair of biscuit products that differed significantly.

In all cases, the significant contrasts show that biscuits that had higher \%age of wheat flour content were rated more highly in their sensory attributes. Hence as wheat flour content decreased, the rating decreased. Sensory attributes of colour and appearance for biscuits $A$ and $J$ were not significantly different $(p>0.05)$. Biscuits $B, F$ and $\mathrm{J}$ were not significantly different in flavor and taste ratings ( $p>0.05)$.

Finally, mixed ANOVA was conducted to determine if there were differences in gender ratings of the sensory attributes of the biscuit products (Table 6). The main effect of the individual sensory attributes of crust colour, appearance, flavor, taste, texture and overall acceptance of the biscuit were significant $(p<0.001)$.

However, gender effect was not significant in all cases $(p>0.05)$, and the interaction between the individual sensory attribute ratings and gender was also not significant $(p>0.05)$.

This implies that although different ratings were given by both males and females, their ratings did not quite differ from one another.

\section{DISCUSSION}

The need to improve the value chain of African traditional foods especially those that are underutilised, like coco- 
Table 6. Sensory evaluation of biscuit products by gender.

\begin{tabular}{|c|c|c|c|c|c|c|c|c|c|c|c|c|}
\hline \multirow{2}{*}{ Sample code } & \multicolumn{2}{|c|}{ Colour } & \multicolumn{2}{|c|}{ Appearance } & \multicolumn{2}{|c|}{ Flavor } & \multicolumn{2}{|c|}{ Taste } & \multicolumn{2}{|c|}{ Texture } & \multicolumn{2}{|c|}{ Overall Acceptability } \\
\hline & $\mathbf{M}$ & $\mathbf{F}$ & M & $\mathbf{F}$ & $\mathbf{M}$ & $\mathbf{F}$ & $\mathbf{M}$ & $\mathbf{F}$ & $\mathbf{M}$ & $\mathbf{F}$ & M & $\mathbf{F}$ \\
\hline$A$ & $4.29 \pm 0.60$ & $4.40 \pm 0.88$ & $3.82 \pm 1.09$ & $4.21 \pm 1.08$ & $4.36 \pm 0.83$ & $4.40 \pm 0.86$ & $4.29 \pm 0.90$ & $4.51 \pm 0.68$ & $4.11 \pm 0.96$ & $4.48 \pm 0.79$ & $4.39 \pm 0.63$ & $4.68 \pm 0.58$ \\
\hline B & $3.86 \pm 1.04$ & $3.70 \pm 1.07$ & $3.32 \pm 1.19$ & $3.47 \pm 1.15$ & $3.86 \pm 1.00$ & $3.79 \pm 0.95$ & $3.89 \pm 1.07$ & $3.84 \pm 1.08$ & $3.68 \pm 1.31$ & $4.20 \pm 0.88$ & $3.79 \pm 0.88$ & $3.95 \pm 0.84$ \\
\hline C & $3.93 \pm 0.94$ & $3.53 \pm 1.07$ & $5.00 \pm 7.71$ & $3.47 \pm 1.17$ & $3.39 \pm 1.10$ & $3.65 \pm 1.03$ & $3.68 \pm 1.16$ & $3.82 \pm 1.05$ & $3.89 \pm 0.92$ & $4.00 \pm 0.97$ & $3.64 \pm 1.03$ & $3.78 \pm 1.06$ \\
\hline D & $3.46 \pm 1.26$ & $3.05 \pm 1.30$ & $3.39 \pm 1.26$ & $3.05 \pm 1.22$ & $3.32 \pm 1.12$ & $3.42 \pm 1.19$ & $3.11 \pm 1.37$ & $3.07 \pm 1.21$ & $3.18 \pm 0.98$ & $3.32 \pm 1.16$ & $3.04 \pm 1.00$ & $3.20 \pm 1.09$ \\
\hline$E$ & $2.71 \pm 1.41$ & $2.67 \pm 1.43$ & $2.93 \pm 1.21$ & $2.60 \pm 1.39$ & $2.82 \pm 1.06$ & $2.61 \pm 1.05$ & $2.36 \pm 1.25$ & $1.84 \pm 0.92$ & $3.43 \pm 1.10$ & $3.20 \pm 1.13$ & $2.54 \pm 1.00$ & $2.36 \pm 1.10$ \\
\hline$F$ & $4.11 \pm 0.88$ & $3.91 \pm 1.09$ & $3.75 \pm 1.00$ & $3.58 \pm 1.16$ & $3.82 \pm 1.02$ & $3.86 \pm 0.90$ & $3.93 \pm 1.12$ & $3.89 \pm 0.96$ & $4.11 \pm 0.99$ & $4.25 \pm 0.86$ & $4.11 \pm 0.79$ & $3.95 \pm 0.84$ \\
\hline G & $3.71 \pm 1.15$ & $3.46 \pm 1.14$ & $3.50 \pm 1.17$ & $3.26 \pm 1.19$ & $3.57 \pm 0.96$ & $3.58 \pm 1.18$ & $3.86 \pm 1.01$ & $3.18 \pm 1.28$ & $3.61 \pm 0.99$ & $3.77 \pm 1.06$ & $3.89 \pm 0.79$ & $3.39 \pm 1.02$ \\
\hline $\mathrm{H}$ & $3.75 \pm 1.14$ & $3.51 \pm 1.31$ & $3.57 \pm 1.26$ & $3.56 \pm 1.30$ & $3.43 \pm 1.00$ & $3.32 \pm 1.31$ & $3.21 \pm 1.67$ & $3.09 \pm 1.20$ & $3.43 \pm 1.14$ & $3.29 \pm 1.29$ & $3.43 \pm 0.96$ & $3.09 \pm 1.18$ \\
\hline | & $3.32 \pm 1.31$ & $3.58 \pm 1.58$ & $3.50 \pm 1.43$ & $3.72 \pm 1.50$ & $3.43 \pm 1.35$ & $3.18 \pm 1.23$ & $2.71 \pm 1.51$ & $2.65 \pm 1.32$ & $3.29 \pm 1.36$ & $3.55 \pm 1.23$ & $3.07 \pm 1.49$ & $3.07 \pm 1.37$ \\
\hline J & $4.43 \pm 0.92$ & $4.37 \pm 0.99$ & $4.46 \pm 0.88$ & $4.30 \pm 1.13$ & $4.11 \pm 0.88$ & $3.65 \pm 1.23$ & $4.25 \pm 0.97$ & $4.02 \pm 1.09$ & $4.86 \pm 0.36$ & $4.54 \pm 0.71$ & $4.68 \pm 0.55$ & $4.09 \pm 0.90$ \\
\hline
\end{tabular}

yam, is timely in recognition that local foods are the basis for the African sustainable diets. Hence the need to explore various options for extending the food uses of many of our traditional food crops.

In the light of the above, the physicochemical and pasting properties of cocoyam flour processed with different methods was determined in order to ascertain its suitability and acceptability in biscuit making. The cocoyam flour properties were compared with wheat flour properties.

Amylose content is one of the factors that influences the clarity of starch pastes, as lower amylose starches are easily dispersed, increasing transmittance and clarity (Mweta et al., 2008). Unblanched white cocoyam flour (U-WCF) had amylose content of $39 \%$, which was closest to that of CWF (31\%) (Table 2). This implies that it is more likely to be desirable for use in confectionery food industry.

Higher swelling capacity indicates higher viscosity; BI-RCF had the highest swelling capacity, which also corresponded to its high peak viscosity (Table 3 ). Although at $p<0.05$ the swell- ling capacity of the flour samples reported in this study were not significantly different (Table 2), but Jangchud et al., 2003, observed that blanching increased the swelling capacity of sweet potato flours. Swelling capacity refers to the expansion accompanying spontaneous uptake of solvent while, solubility index (SI) is the amount of water soluble solids per unit weight of the sample (Omueti et al., 2009). Swelling capacity is regarded as quality criterion in some good formulations such as bakery products (Osungbaro et al., 2010). The solubility of the blanched and unblanched flour samples were significantly different at $p<0.05$, compared to CWF. These solubility values for cocoyam flours in this study fell within the range $10.00-26.67 \%$, reported by Ojinnaka et al. (2009), for cocoyam starch.

\section{Pasting properties}

Pasting properties of flours are used to determine their suitability and desirability of baked products in the food industry. These parameters include viscocity, gelatinization time, temperature and retrogradtion tendencies. In this study, BI-RCF had the highest peak viscocity (PV), 267.580 RVU, while CWF had the least PV, 145. 450RVU; followed by U-CWF, 161.795RVU. Peak viscosity (PV) indicates the water-binding capacity of the starch or mixture; it is the ability of the starch to swell before it physically breaks down (Odedeji and Adeleke, 2010). In this study, the high PV of the blanched cocoyam flour corresponded with their high amylose content, and starch content while the unblanched cocoyam flours, which had lower amylose content and starch content, had lower PVs (Tables 2 and 3).

Peak viscosity is often correlated with the final product quality. It also provides an indication of the viscous load likely to be encountered during mixing (Adebowale et al., 2008). This suggests that the blanched cocoyam flours will form a thicker viscous gel on cooking, more than the blanched cocoyam flours may be more suitable for products which require high gel strength (Odedeji and Adeleke, 2010). The PV and final 
viscosities (FV) of the blanched flours were significantly higher than the values obtained for the unblanched flours and the CWF. However, the reverse was reported for potato flours by Jangchud et al. (2003), the peak and final viscosities of blanched flours were reported to be lower than those of unblanched flours.

$\mathrm{FV}$ is the most commonly used parameter to define the quality of a particular starch-based sample, as it indicates the ability of the material to form a viscous paste or gel after cooking and cooling as well as the effect of texture modifiers on the physicochemical resistance of the paste to shear force during stirring (Odedeji and Adeleke, 2010). The value, $167.46 \pm 8.2 R V U$, obtained for final viscosity of cocoyam flour (unfermented) by Oke and Bolarinwa (2012), differed slightly from the values obtained in this study for unblanched red and white cocoyam flour (270.38 $\pm 1.78 \mathrm{RVU}$ and $243.88 \pm 4.42 \mathrm{RVU})$, respectively.

The trough, which can also be referred to as shear thinning, holding strength, or hot paste viscosity, is the minimum viscosity value in the constant temperature phase of the RVA profile and measures the ability of paste to withstand breakdown during cooling (lkegwu et al., 2010; Adebowale et al., 2008). There were significant differences between the troughs of blanched and unblanched cocoyam flour. The blanched cocoyam flours had higher holding strength (trough) than the unblanched flours. This means that the blanched cocoyam flours were likely to withstand breakdown during cooling than the unblanched flours.

Breakdown in viscosity to a holding strength (trough) usually occurs when a sample is subjected to a period of constant high temperature and mechanical shear stress. The ability of a mixture to withstand heating and shear stress that is usually encountered during processing is an important factor for many processes especially those requiring stable paste and low retrogradation/syneresis (Adebowale et al., 2008). In this study, the breakdown values obtained especially for the unblanched red and white cocoyam flours, $35.21 \pm 0.30$ and $5.92 \pm 1.06 \mathrm{RVU}$, respectively, were much lower than the values obtained by Oke and Bolarinwa (2012).

However, the breakdown viscosity for these authors for unfermented and fermented cocoyam flours were closer to the values obtained for blanched red and white cocoyam flours, respectively. Unfermented cocoyam flour, $24 \mathrm{~h}$ cocoyam flour and $48 \mathrm{~h}$ cocoyam flour, breakdown viscosities were $62.84 \pm 5.1,58.83 \pm 1.9$ and 66.96 $\pm 5.3 \mathrm{RVU}$, respectively (Oke and Bolarinwa, 2012); in the present study, breakdown viscosities for the blanched red and white cocoyam flour were $70.25 \pm 7.54$ and 58.92 $\pm 3.06 \mathrm{RVU}$, respectively. Furthermore the latter values were closer to the breakdown viscosity of the CWF obtained in this study, which was $61.00 \pm 3.18 \mathrm{RVU}$. The implication is that $\mathrm{BI}-\mathrm{WCF}, \mathrm{BI}-\mathrm{RCF}$ and CWF have a better chance of withstanding heating and shear stress during processing.
The "setback" value is related to the amylose content, retrogradation and reordering of starch molecules (Chanapamokkhot and Thongngam, 2007; Jangchud et al., 2003). High set back is associated with syneresis, or weeping, during freeze/thaw cycles (Perten Instruments, 2010). CWF had the lowest set back of 85.585RVU, while $\mathrm{BI}-\mathrm{RCF}$ had the highest set back value; 118.835RVU. The set back of U-WCF, 88.000RVU was not significantly different from that of CWF. This suggests that both CWF and U-WCF will have the lowest rate of retrogradation and syneresis.

According to Omueti et al. (2009), low set back is an indication that the starch has a low tendency to retrograde or undergo syneresis. However, the high set back values for cocoyam flour in this study were contrary to those of Oti and Akobundun (2007) results, where they obtained 0.00 setback values for their cocoyam-soybeancrayfish flour blends.

The peak time is a measure of the cooking time (Adebowale et al., 2008). Table 3 shows that the blanched cocoyam flours had the lower peak times than the unblanched cocoyam flours and CWF (5.930): BIRCF, $4.775 \mathrm{~min}$ and BI-WCF, 4.97min. This could be attributed to the fact that partial gelatinization had occurred during blanching of the cocoyam chips before processing it into flour. The peak time for unblanched cocoyam flours $(5.77 \pm 0.04$ and $5.04 \pm 0.12)$, respectively was close to the peak time obtained for unfermented cocoyam flour $(5.68 \pm 0.1 \mathrm{~min})$ by Oke and Bolarinwa (2012).

Pasting temperature is the temperature at the onset of gelatinization (Adebowale et al., 2008). In this study, the pasting temperature ranged from $61.73 \pm 0.04$ to $61.95 \pm 0.42^{\circ} \mathrm{C}$; these values for blanched and unblanched cocoyam flours and the CWF were not significantly different. Values for pasting temperature for unfermented and fermented cocoyam flours obtained by Oke and Bolarinwa (2012) were close to the pasting temperature values obtained for unblanched and blanched cocoyam flours in the present study.

\section{Sensory evaluation}

Generally, for all the sensory attributes, colour, appearance, taste, flavor, texture and overall acceptance, there was significant statistical difference in the rating within each attribute. This implies that the differences observed were actually due to the manipulations i.e. the substitution levels of wheat and cocoyam flour affected the preference of the panelists.

\section{Colour}

In terms of biscuit crust colour, the $100 \%$ wheat flour biscuit and the commercial biscuit were the most pre- 


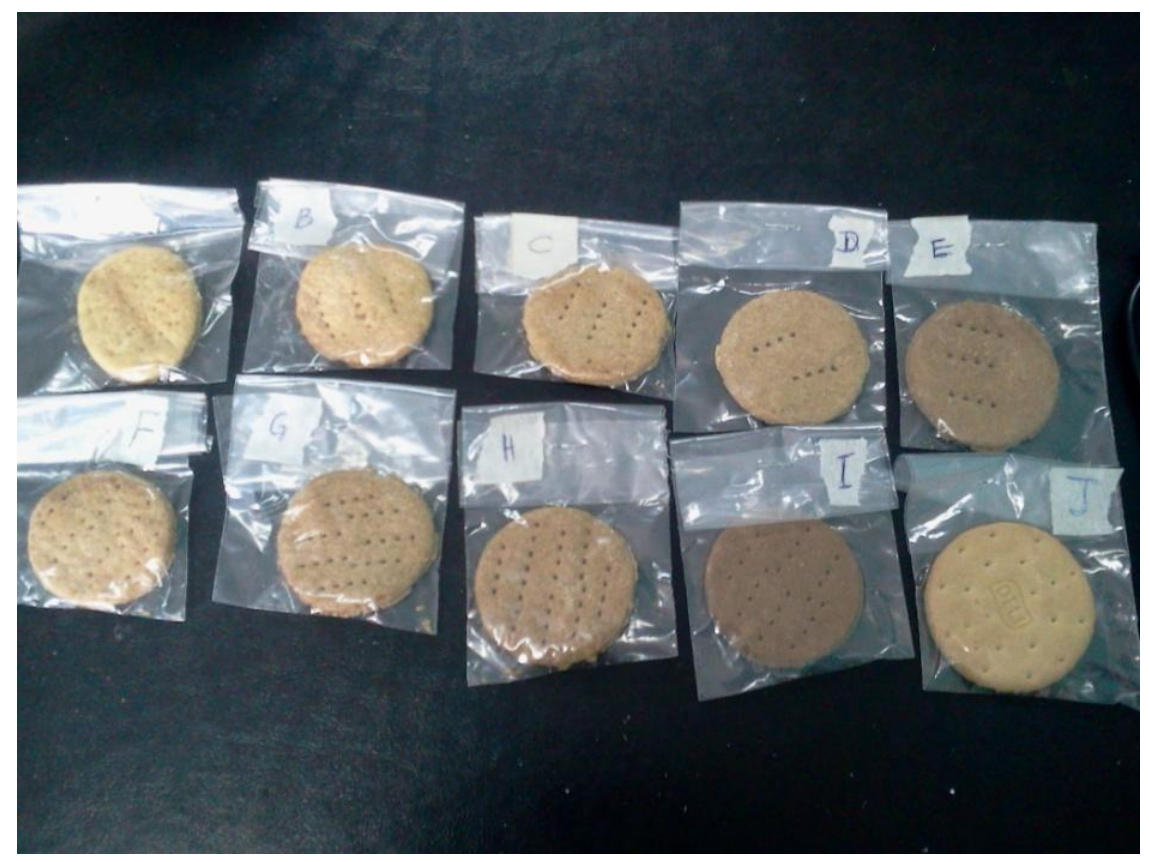

Plate 1. Samples of baked wheat/ cocoyam flour biscuits.

preferred. This was closely followed by the $10 \%$ red cocoyam flour and white cocoyam flour substituted biscuits, respectively. This preference was similar between the male female participants. The preference for the biscuit crust colour reduced considerably as the quantity of cocoyam flour in the biscuit increased; the biscuits became very dark brown in colour (Plate 1).

The results in Table 5 shows that higher ratings were given to the biscuit products with lower quantities of cocoyam flour substitution. This implies that the crust colour of these biscuit products A $(100 \%$ wheat flour biscuit), $J$ (commercial biscuit), $F$ (10\% red cocoyam flour biscuit), B (10\% white cocoyam flour biscuit), and C, (30\% white cocoyam flour) were most preferred because they had the highest rating.

Between biscuits $A$ and $J$, the mean rating was not statistically significant. The mean comparisons between the cocoyam flour substituted biscuits were not significant. When the ratings were examined by gender, there was no statistical difference between the preference for the colour of biscuit crust between male and female participants.

However, the crust colour was given different ratings by both gender in this order of preference: female and male participants' ratings, respectively: A $(4.40 \pm 0.88)$, J (4.37 \pm 0.99$), F(3.91 \pm 1.09,4.11 \pm 0.88)$, B $(3.70 \pm 1.07)$, C (3.53 \pm 1.07$)$; male participants' rating: $A(4.29 \pm 0.60)$, J $(4.43 \pm 0.92), C(3.93 \pm 0.94)$ and $B(3.86 \pm 1.04)$.

Although the means (Table 5) shows that males rated the colour of the biscuit crust of biscuit $C$ higher than biscuit $B$ and vice versa for the female, these were not statistically significant. Biscuits D (50\% white cocoyam flour), E (100\% white cocoyam flour), and I (100\% red cocoyam flour) were the least preferred.

This could be attributed to the fact that as the cocoyam flour content in the biscuit products increased, the crust colour became darker (Plate 1) thereby making them less desirable.

\section{Appearance}

The rating for the biscuit appearance shows that biscuits A (100\% wheat flour biscuit), J (commercial biscuit), and C (30\% white cocoyam flour biscuit) were the most preferred.

The statistical difference between the mean ratings was also significant. When further statistical analysis was done to separate the means, only biscuits, $B$ and $C, F$ and $\mathrm{G}, \mathrm{G}$ and $\mathrm{H}, \mathrm{H}$ and $\mathrm{I}$, were not statistically significant. This time around, none of the biscuits substituted with red cocoyam flour had a favourable rating.

When the observation was disaggregated by gender, though there was no statistical difference observed, mean ratings by male and female were however different: biscuit J $(4.46 \pm 0.88,4.30 \pm 1.13), \quad A \quad(3.82 \pm 1.09$, $4.21 \pm 1.08), C(5.00 \pm 7.71,3.47 \pm 1.17)$. Hence, the order of preference for male participants is biscuits $\mathrm{J}, \mathrm{C}$ and $\mathrm{A}$; while the order of preference for female participants is biscuits $\mathrm{J}, \mathrm{A}$, and $\mathrm{C}$.

\section{Flavor}

The sensory ratings showed that the most preferred products were the $100 \%$ wheat flour biscuit, $10 \%$ white 
cocoyam flour, $10 \%$ red cocoyam flour substituted biscuits and commercial biscuits. Between male and female participants respectively, the preference for these biscuits were also similar.

\section{Taste}

The ratings for taste of the biscuits by the participants showed that $100 \%$ wheat flour biscuit, commercial biscuit, and $10 \%$ white and red cocoyam flour substituted biscuits, respectively, were the most preferred products. The rating between male and female participants were similar however, an observation of the mean ratings in Table 4 shows that female participants also had a high mean rating for the taste of $30 \%$ white cocoyam flour substituted biscuits in addition to the former.

\section{Texture}

The mean ratings shows that products from $100 \%$ wheat flour, commercial biscuits, $10 \%$ red and white cocoyam flour substituted biscuits, respectively and 30\% white cocoyam substituted biscuits were the most preferred by the participants. Preference for products between the male and female participants, respectively, showed similar trends. However, the male participants had a low mean rating for the texture of the $10 \%$ white cocoyam flour substituted biscuits.

\section{Overall acceptability}

The mean rating followed the trend for all other sensory attributes: $100 \%$ wheat flour biscuit, commercial biscuit, $10 \%$ red and white cocoyam flour substituted biscuits, were the most preferred products overall. This trend was observed to also be similar between male and female participants, respectively. Furthermore, from the observed results, taste of the biscuits had the strongest significant positive correlation with the overall acceptance of the various biscuit products.

The findings of this study are in line with previous similar studies, whereby wheat flour was partially substituted with flours from other sources especially from tubers (Aniedu, 2006; Sanful and Darko, 2010; Adeleke and Odedeji, 2010), in order to extend their uses. It was observed that at substitution levels with white cocoyam flour beyond $30 \%$, preference decreased while for red cocoyam flour, the preference decreased significantly when substitution level exceeded $10 \%$.

Studies by Ojinnaka et al. (2009) showed that the use of cocoyam starch in cookies production at 5 and $10 \%$ levels respectively, had desirable sensory attributes and were acceptable by panelists in their study. Adeleke and Odedeji (2010), equally reported that blending sweet potato flour (which is a tuber), with wheat flour up to $20 \%$ substitution level, produced samples which can be used for production of confectioneries with improved functional properties. Plantain and wheat flour blend of 20 and $40 \%$ partial substitution have also been reported to be suitable and acceptable in making biscuits (Mepba et al., 2007). Sanful and Darko (2010) observed in their study that cassava and cocoyam flour could be used to substitute wheat flour for up to $30 \%$ in the production of rock cakes, which are acceptable by consumers.

\section{Conclusion}

This study shows that the physicochemical and pasting properties of the unblanched red and white cocoyam flours were similar to those of the commercial wheat flour. Also, partial substitution of wheat flour with cocoyam flour is possible and biscuits made from this combination with up to $10 \%$ substitution for both red and white cocoyam flours were acceptable. Hence, the use of cocoyam flour partially substituted with wheat flour should be further explored in pastry making. This will extend as well as increase the utilisation options for this underutilised tuber beyond its current basic use. This diversification in the value chain for cocoyam can also become an increased source of income for cocoyam farmers and processors in Nigeria.

\section{REFERENCES}

Adeleke RO, Odedeji JO (2010). Functional properties of wheat and sweet potato flour blends. Pak. J. Nutr. 9:535-538.

Aniedu C (2006). Development of secondary food forms of cocoyams (Colocasia spp). J. Agric. For. Soc. Sci. 4(2): 126-130.

Chanapamokkhot $\mathrm{H}$, Thongngam M (2007). The chemical and physicochemical properties of sorghum starch and flour. Kasetsart J. (Nat. Sci.) 41:343-349

FAO (2007). FAOSTAT Statistics Division of the Food and Agriculture Organization, http://faostat.fao.org.

Ikegwu OJ, Okechukwu PE, Ekumankana EO (2010). Physico-chemical and pasting characteristics of flour and starch from achi Brachystegia eurycoma seed. J. Food Technol. 8(2):58-66.

Iwuoha Cl, Kalu FA (1995). Calcium oxalate and physicochemical properties of cocoyam (Colocasia esculenta and Xanthosoma sagittifolium) tuber flours as affected by processing. Food Chem. 54:61-66.

Jangchud K, Phimolsiripol Y, Haruthaithanasan V (2003). Physicochemical properties of sweet potato flour and starch as affected by blanching and processing. Starch 55:258-264

Jennings DL (1987). Starch crops. In: CRC Handbook of plant Science in Agriculture. Volume II. (Eds. B. R. Christie). CRC Press, Inc. Boca Raton, Florida, USA. pp. 137-143.

Mepba HD, Eboh L, Nwaojigwa SU (2007). Chemical composition, functional and baking properties of wheat-plantain composite flours. Afr. J. Food Agric. Nutr. Dev. 7(1):1-22.

Mweta DE, Labuschagne MT, Koen E, Benesi IRM, Saka JDK (2008). Some properties of starches from cocoyam (Colocasia esculenta) and cassava (Manihot esculenta Crantz.) grown in Malawi. Afr. J. Food Sci. 2: 102-111.

Ndoumou DO, Tsala GN, Kanmegne G, Balangé AP (1995). In vitro induction of multiple shoots, plant generation and tuberization from shoot tips of cocoyam. C. R. Acd. Sci. Paris, Sciences de la vie/ life Sciences 318:773-778.

Odedeji JO, Adeleke RO (2010). Pasting characteristics of wheat and 
sweet potato flour blends. Pak. J. Nutr. 9 (6): 555-557.

Ojinnaka MC, Akobundu ENT, Iwe MO (2009). Cocoyam starch modification effects on functional, sensory and cookies qualities. Pak. J. of Nutr. 8(5):558-567.

Omueti O, Otegbayo B, Jaiyeola O, Afolabi O (2009). Functional properties of complementary diets developed from soybean (Glycine max.), groundnut (Arachis hypogea) and crayfish (Macrobrachium Spp). EJEAFChe. 8(8):563-573.

Onwueme IC, Charles WB (1994). Cultivation of cocoyam. In: Tropical root and tuber crops. Production, perspectives and future prospects. FAO Plant Production and Protection Paper 126, Rome. pp. 139-161.

Osungbaro TO, Jimoh D, Osundeyi E (2010). Functional and pasting properties of composite Cassava-Sorgum flour meals. Agric. Biol. J. N. Am. 1(4):715-720
Oti E, Akobundu ENT (2007). Physical, functional and amylograph pasting properties of cocoyam-soybean-crayfish flour blends. Niger. Food. J. 25(1):161-170.

Sanful RE, Darko S (2010). Production of Cocoyam, Cassava and Wheat flour composite rock cake. Pak. J. Nutr. 9(8): 810-814.

Sanni LB, Maziya-Dixon AO, Onabolu BE, Arowosafe AE, Okoruwa RU, Okechukwu AGO, Dixon ADI, Waziri IP, Ezedinma C, Ssemakula G, Lemchi J, Akoroda M, Ogbe F, Tarawali G, Okoro E, Geteloma C (2006). Cassava recipes for household food security. IITA Integrated Cassava Project, Ibadan, Nigeria.

Watanabe KZ (2002). Challenges in biotechnology for abiotic stress tolerance on root and tubers. JIRCAS Working Reports 75-83. 